Hydrology and Earth System Sciences, 8(2), 151-159 (2004) C EGU

\title{
Seagrasses and sediment response to changing physical forcing in a coastal lagoon
}

\author{
J. Figueiredo da Silva ${ }^{1}$, R.W. Duck ${ }^{2}$ and J.B. Catarino ${ }^{1}$ \\ ${ }^{1}$ Departamento de Ambiente e Ordenamento, Universidade de Aveiro, 3810-193 Aveiro, Portugal \\ ${ }^{2}$ Department of Geography, University of Dundee, Dundee, DD1 4HN, Scotland \\ Email of corresponding author: jfs@ua.pt
}

\begin{abstract}
The Ria de Aveiro is an estuary-coastal lagoon system connected to the Atlantic Ocean by a channel with a cross-sectional area that, for more than a century, has increased steadily, partly because of dredging over the last 50 years. Local ocean tides, with amplitudes of up to $3 \mathrm{~m}$, are today transmitted to the lagoon by the single, engineered inlet channel and propagate to the end of the lagoon channels as a damped progressive wave. The increase in tidal amplitude with time has affected the lagoon ecosystem and the water has become more saline. Seagrass beds are important indicators of ecosystem change; until 1980, much of the lagoon bed was covered by seagrasses (Zostera, Ruppia, Potamogeton), which were collected in large quantities for use in agriculture. After 1960, the harvesting declined and the seagrass beds became covered in sediment, so that the area of seagrasses decreased substantially despite the decline in the quantity collected. The change in the pattern of seagrass populations can be related to changes in the physical forcing associated with increased tidal wave penetration. This has, in turn, induced transport and redistribution of coarser, sandy sediment and increased re-suspension and turbidity in the water column. However, the initiating cause for this ecosystem change was dredging which, since the 1950s, has been used increasingly to widen and deepen the channels.
\end{abstract}

\section{Introduction}

The Ria de Aveiro, at approximately $41^{\circ} \mathrm{N}, 9^{\circ} \mathrm{W}$, is the most remarkable geomorphological feature of the Atlantic Ocean coast of northern Portugal. It comprises a combined shallow estuary-coastal lagoon with a complex morphology and productive ecosystem. The physical system is characterised by many branching channels connected to the ocean by a single tidal channel, via an intervening tidal lagoon (Fig. 1). Seagrasses, formerly abundant in the sub-tidal zones, have for centuries been harvested for agriculture. Economic and social factors led to a decline in the industry after the 1960s although seagrasses were still in plentiful supply (Santos and Duarte, 1991; Silva, 1985). In the 1990s, however, seagrass species experienced a marked reduction such that they are now completely absent from sub-tidal areas and are found only in restricted inter-tidal zones. This change, of which former harvesters are well aware, is still undocumented. This paper identifies and investigates the factors, including changes in the salinity and sedimentation regimes, that have led to this rapid and widespread decline in the seagrass populations of the Ria de Aveiro system.

\section{Methods}

Information on the amounts of seagrasses collected from the Ria de Aveiro since the late 1880s was obtained, principally from Silva (1985), with additional data on the subsidised collection of seagrasses in the late 1980s from the Administração do Porto de Aveiro. In the present investigation, interviews with former seagrass collection workers detailed the evolution of the activity during the last two decades until its cessation. The Capitania do Porto de Aveiro provided information on the variation in time of the numbers of boats involved in the seagrass collection industry.

The areas in the lagoon presently covered by seagrasses and macroalgae were identified by observations from a boat and also from a light aircraft. The latter remote observations (flights carried out: 11/9/2002, 26/9/2002, 19/1/2003, 5/4/ 2003, 31/5/2003) provided airborne oblique colour photographs, for subsequent geometric correction to determine the surface areas covered by seagrasses. From locations shown in Fig. 1, macroalgae and seagrass samples were collected by hand from within a $0.5 \times 0.5 \mathrm{~m}$ sampling 


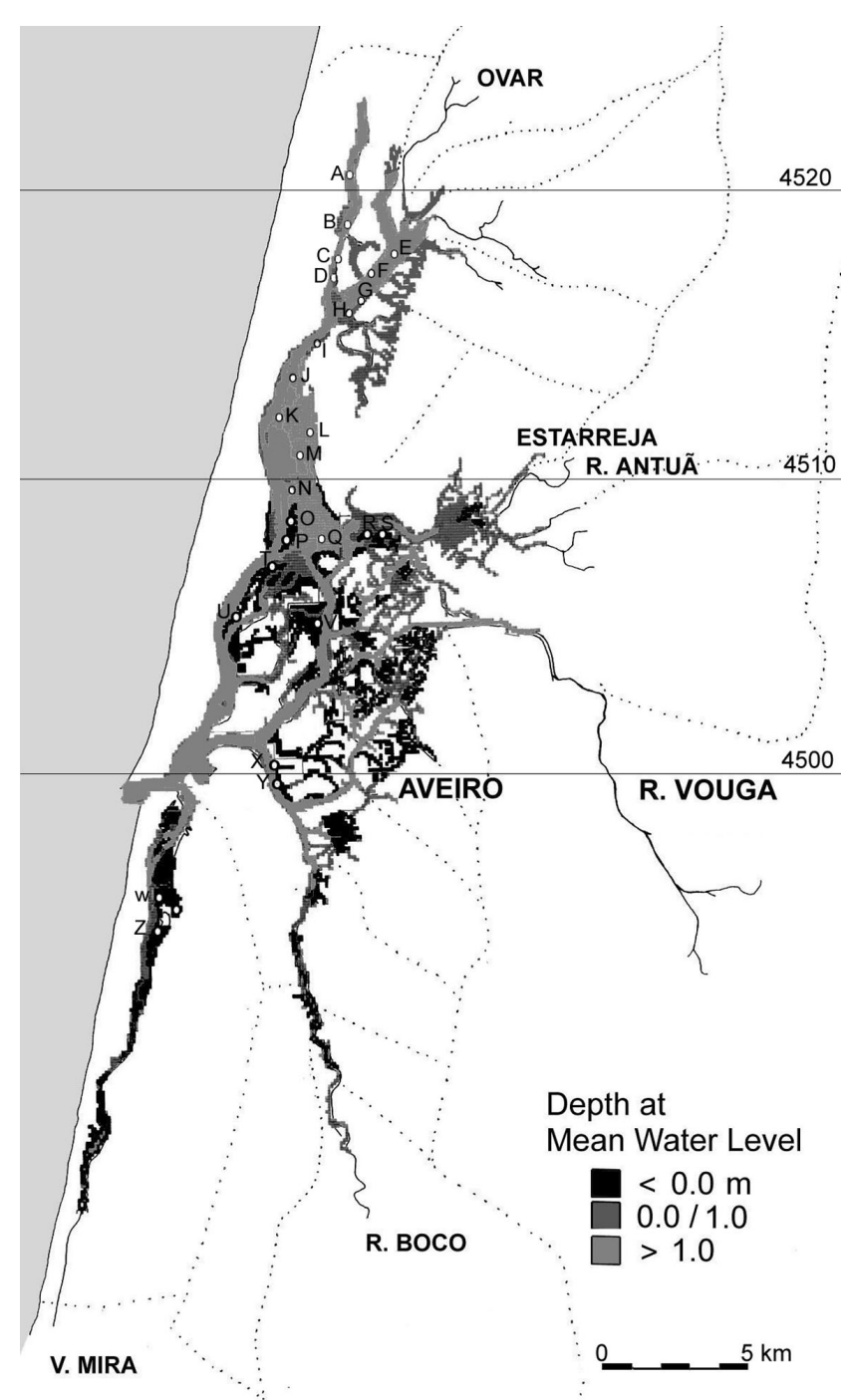

Fig. 1. The Ria de Aveiro, showing in light grey the sub-tidal zone and in dark grey and black the inter-tidal zones (below mean water level). Sampling stations are marked by open circles and letters. UTM Y-co-ordinate $(\mathrm{km})$ is given on the right side.

quadrat on several dates in September and October 2002 and in February and June 2003. The quadrat was placed at one or several points at each sampling station, considered representative of the vegetation in the area. Each sample was washed in the field to remove sediment and transported to the laboratory, where the species were separated. The wet weight, air-dried weight, weight dried at $60^{\circ} \mathrm{C}$ and volatile content (at $550^{\circ} \mathrm{C}$ ) were determined for each species.

In the field, water salinity was measured and samples of bottom sediments were taken in the Canal de Ovar (Fig. 1), one of the principal channels of the ria system and the one which formerly hosted abundant populations of seagrasses. Salinity was determined in 2003 at the water surface and at $1 \mathrm{~m}$ depth, at high and low tide along the thalweg of the channel using a WTW Salinometer (Model LF330), with position fixing by Magellan Promark X-CM GPS. For comparative purposes, these measurements were made at the stations located by Silva (1985) and fixed with reference to known points on the channel margins; these were used for salinity determinations in 1979/80 using a Yellow Springs Salinometer (Model 33). Samples of bottom sediments, collected by hand from both sub-tidal and intertidal areas at low water in October 2002, afforded comparison with a similar suite of samples collected by Silva (1985) in 1979. Wet sieving through a $63 \mu \mathrm{m}$ aperture mesh, after sample treatment with $\mathrm{H}_{2} \mathrm{O}_{2}$ to remove organic matter and dispersion with sodium hexametaphosphate, separated the sand from the silt plus clay size fraction. Then, grain size distribution curves were determined after dry sieving of the sand fraction and sedimentation of the silt plus clay fraction .

\section{Morphological evolution of the Ria de Aveiro}

The origin and evolution of the Ria de Aveiro are related to the southward growth of a major sand spit which encloses the lagoon from the Atlantic Ocean to the west. Sand is transported along shore, principally in a north to south direction, by the littoral drift, and particles accumulated on the beach are also moved inland by winds, forming sand dunes which extend for $100 \mathrm{~km}$ to the south of the mouth of the Douro River. In the past, wind caused these sand dunes to move but they are now mainly 'fixed' by pinewoods.

Silva and Duck (2001) reviewed the morphological evolution of the Ria de Aveiro over the last 200 years, as documented by maps. Around 1800, the ria was almost isolated from the Atlantic Ocean by southward migration of the major sand spit which today encloses the lagoon. Extension and growth of this spit controlled the evolution of the system, by reducing, sharply, the tidal amplitude in the long and narrow natural channel connecting the lagoon to the ocean. In 1802, tidal ranges were between 0.07 and $0.13 \mathrm{~m}$ over most of the lagoon (Carvalho, 1947) and in wet periods, up to nine months in a year, all of the area of the lagoon remained continually flooded by river water. Also, the beds of the influent rivers were being infilled by sediment derived from their catchment areas; thus, the ria, at that time, was a choked coastal lagoon ( Kefevre, 1994).

This natural evolutionary trend was halted in 1808 by the construction of a new inlet/outlet channel with a cross sectional area of $c .1000 \mathrm{~m}^{2}$ and fixed by a breakwater, $18 \mathrm{~km}$ to the north of the natural channel. As a result, the tides within the lagoon increased in amplitude to over $1 \mathrm{~m}$. Construction of walls and dredging work to maintain the 
channel width and depth for navigation to the port of Aveiro continues to this day. Indeed, such activities have controlled the evolution of the lagoon to its present state (Silva and Duck, 2001).

The changed hydrographic regime allowed the rapid discharge of high river flows, thereby preventing flooding and the upstream accumulation of sediment loads. The currents created by tidal propagation dispersed the sediments transported by the major rivers into the lagoon. Assessments of the area of the lagoon then permanently covered by water varied from 60 to $80 \mathrm{~km}^{2}$ (Loureiro, 1904; Leitão, 1906; Nobre et al., 1915). This included some 270 salt pans, built over inter-tidal flats, which were enclosed by mud dikes, and covered an area of $c .17 \mathrm{~km}^{2}$ around the town of Aveiro. This area was also covered by water but was isolated from the tidal oscillation.

Starting in the 1950s, the inlet channel was improved by construction of breakwaters and deepened by dredging as far upstream as the port of Aveiro. In consequence, the cross sectional area of the channel at Barra (Fig. 2) is now over $4000 \mathrm{~m}^{2}$, and the upstream channels towards the port of Aveiro have similar cross sections. The increase in crosssectional area has caused a steady increase in the amplitude of tides inside the lagoon (up to $2.5 \mathrm{~m}$ ), as well as further deepening of the lagoon channels. Most of the old salt pans are now open to tidal oscillation and unreinforced mud dikes have now been partially destroyed due to the stresses imposed by the larger tidal ranges. Channels in the lagoon are widening and increasing in depth (Fig. 3), while some of the mud flat areas have been elevated as a result of sedimentation (Fig. 3, see also Fig. 4 of Silva and Duck, 2001). The resulting changes in bathymetry have increased the 'channelisation' effect of the tidal flow in the lagoon.

The volume of sediment deposited on mudflats is not known but that lost from the channels between 1952 and 1987 was estimated as $58.5 \times 10^{6} \mathrm{~m}^{3}$ (Rodrigues et al., 1989).

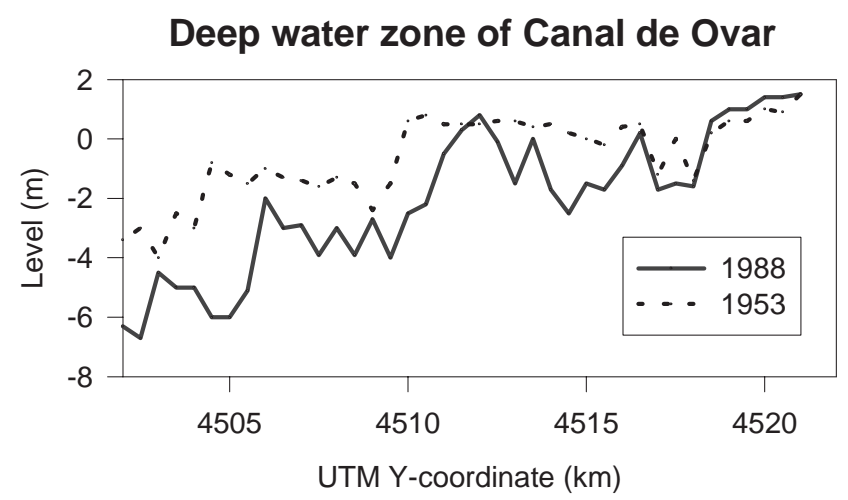

Tidal flat of Canal de Ovar

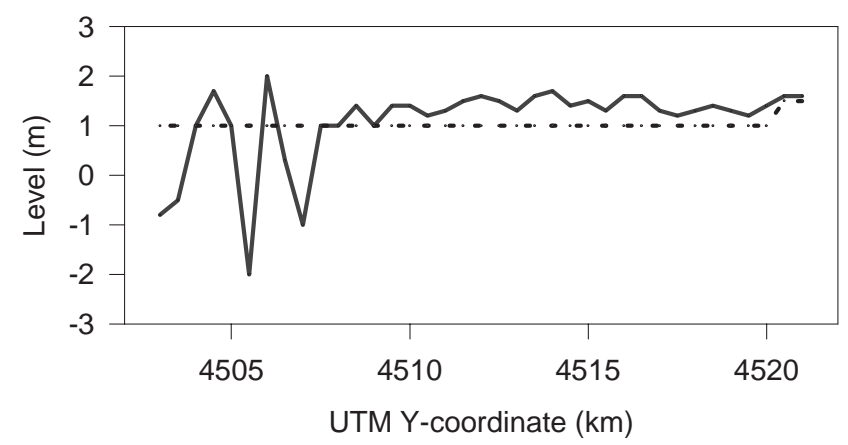

Fig 3. Bottom profiles along the Canal de Ovar in 1988 compared with 1953. Upper panel profile along the deeper points of the channel. Lower panel profile along the mud flat zones that were located, in 1953, at $1 \mathrm{~m}$ below mean sea level.

The volume of sediment dredged (Fig. 4) in the same period was $16.6 \times 10^{6} \mathrm{~m}^{3}$ (Teixeira, 1994), accounting for approximately $1 / 3$ of the total volume of sediment lost from channels. Most of the dredging operations were carried out in the main navigation channel but, during the 1990s, large quantitities of sediment $\left(>2 \times 10^{6} \mathrm{~m}^{3}\right.$; Administração do Porto de Aveiro, pers. comm.) were also removed from the inner channels.

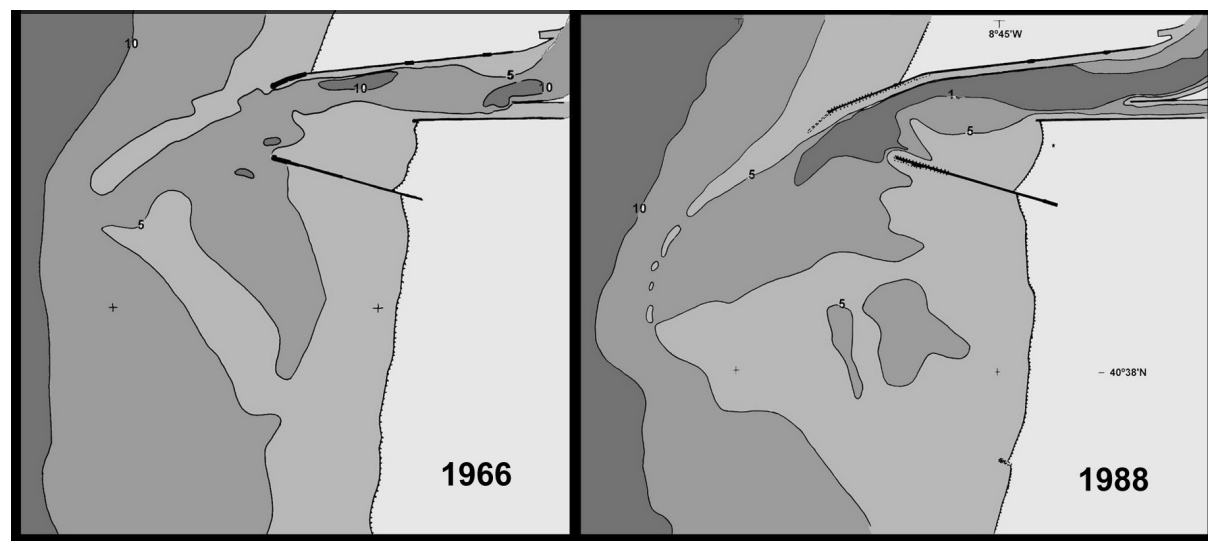

Fig. 2. Recent evolution of the inlet channel at Barra. Areas marked in dark grey are deeper than $10 \mathrm{~m}$. 

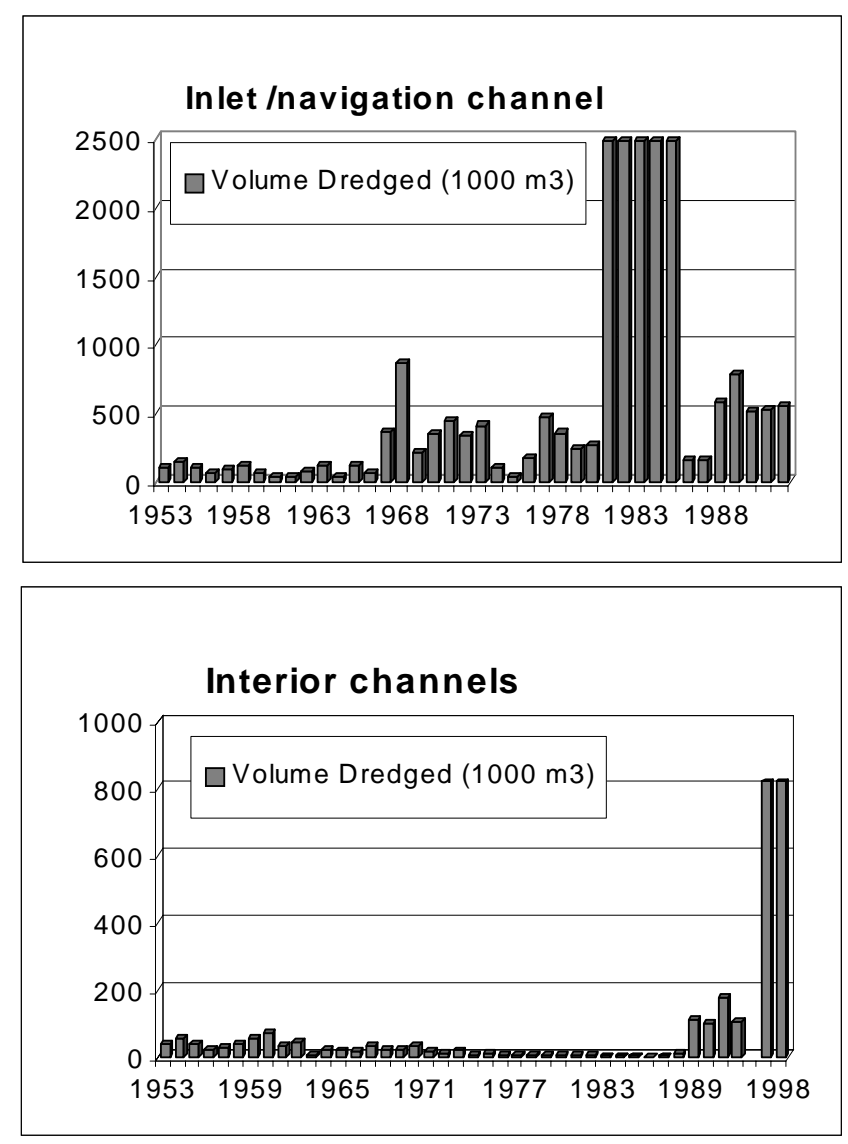

Fig. 4. Volumes of sediment dredged from the Ria de Aveiro between 1952 and 1998 .

\section{Tidal prism and salinity change}

Prior to the opening of the new channel in 1808 , the water level of the lagoon was determined mainly by river flow. The winter level, during river floods, was up to $2 \mathrm{~m}$ higher than the summer level. In summer, the tidal oscillation was about $0.1 \mathrm{~m}$, observed over an area of $50 \mathrm{~km}^{2}$, corresponding to a tidal prism of $5 \times 10^{6} \mathrm{~m}^{3}$ (Silva and Duck, 2001). The increase in tidal amplitude, caused by the construction of the new inlet and subsequent deepening of channels, is associated with a mean water level in the ria system that is now closer to mean sea level (m.s.l.). As a result, by 1936 the tidal prism had increased to $25 \times 10^{6} \mathrm{~m}^{3}$, by 1956 to $65 \times 10^{6} \mathrm{~m}^{3}$ and by 2000 , associated with tidal amplitudes of up to $3 \mathrm{~m}$, to $c .110 \times 10^{6} \mathrm{~m}^{3}$ (Silva and Duck, 2001).

As a consequence of the progressive increase in tidal prism since 1808 , there has been a corresponding change in the spatial distribution of salinity within the Ria de Aveiro system. This is illustrated with reference to the areas of three salinity zones that are present during summer conditions (fresh water zone, transition zone and marine zone, the vegetative characteristics of which are detailed in Table 1). In 1910 (Fig. 5), the marine zone, characterised by salinities $>30$ psu, extended inland from the entrance channel for no more than $4 \mathrm{~km}$ (based on information in Nobre et al., 1915). At this time, the transition zone (salinity range 5-30 psu) characterised the whole of the lagoon. However, salinities measured in August 1963 by Brigada Hidrográfica ${ }^{\circ} 2$ (unpublished report) show that, by the 1960s, fully marine waters penetrated the major channels up to $15 \mathrm{~km}$ from the sea and the freshwater zone (salinity $<5 \mathrm{psu}$ ) was pushed some $2 \mathrm{~km}$ inland. By 2000 such conditions existed even further inland, thereby further reducing the area of the transitional zone (Fig. 5).

The variations in salinity (measured at the water surface and at $1 \mathrm{~m}$ depth) at high and low water along the length of the Canal de Ovar in 1979/80, as compared with 2003, are shown in Fig. 6 for winter (February 1979, February 2003) and summer (June 1980, June 2003) flow conditions. In general, water salinities have increased, typically by between 2 and 10 psu at all points along the channel since the 1979/ 80 observations. Furthermore, at high tide in winter conditions of high freshwater river discharge, water with salinities characteristic of the marine zone penetrates up to $3 \mathrm{~km}$ further upstream than in 1980.

\section{Changes in areas of seagrasses in the Ria de Aveiro}

A very significant ecosystem change has been the decline in the area of the transition zone of the Ria de Aveiro that is covered by species of seagrasses. Specifically, this took place during the 1990s and is well illustrated with reference to the Canal de Ovar (Fig. 7) by comparing the situation in 1984 with that in 2003 . In 1984, some $8 \mathrm{~km}^{2}$ of the subtidal areas were covered with seagrasses Potamogeton pectinatus, Ruppia cirrhosa and Zostera noltii (also in the inter-tidal zones), mixed with Enteromorpha sp., Lola lubrica and Gracilaria verrucosa. The total wet biomass (mainly sub-tidal) was $2 \times 10^{4} \mathrm{t}$, with a dry weight range of $300-600 \mathrm{gm}^{-2}$. By 2003, the area covered by seagrasses in the Canal de Ovar had fallen to $1 \mathrm{~km}^{2}$, entirely within the inter-tidal zone. Z. noltii had become the dominant species, mixed with Enteromorpha sp., Ulva sp. and G. verrucosa. Table 2 presents the mean and standard deviation of the dry weight of the plants found in the intertidal areas that are still vegetated. In the sub-tidal zone, where seagrasses had thrived previously, only algae (G. verrucosa and Enteromorpha) were present. The total wet biomass (entirely inter-tidal) was reduced by an order of magnitude to $1.5 \times$ $10^{3} \mathrm{t}$, with a dry weight range of $100-300 \mathrm{gm}^{-2}$. This example, from the Canal de Ovar, is typical of the transition 
Table 1. Salinity zones of the Ria de Aveiro and their corresponding vegetation characteristics.

Fresh water zone ( $<5$ psu, upper estuarine reaches):

- $\quad$ Submerged plants, e.g. Myriophyllum, Potamogeton, Chara, Cladophora

- Marsh plants e.g. Phragmites and other graminae

Transition zone (5-30 psu, lagoon):

- Submerged plants (moliço), e.g. Potamogeton pectinatus, Ruppia cirrhosa, Zostera noltii, Lola, Enteromorpha, Ulva, Gracilaria

- Marsh plants, e.g. Juncus, Scirpus

Marine zone (>30 psu, lower reaches of channels):

- Inter-tidal plants, e.g. Zostera, Enteromorpha, Ulva, Gracilaria, Fucus

- Marsh plants, e.g. Spartina, Salicornia, Suaeda, Atriplex, Halimione
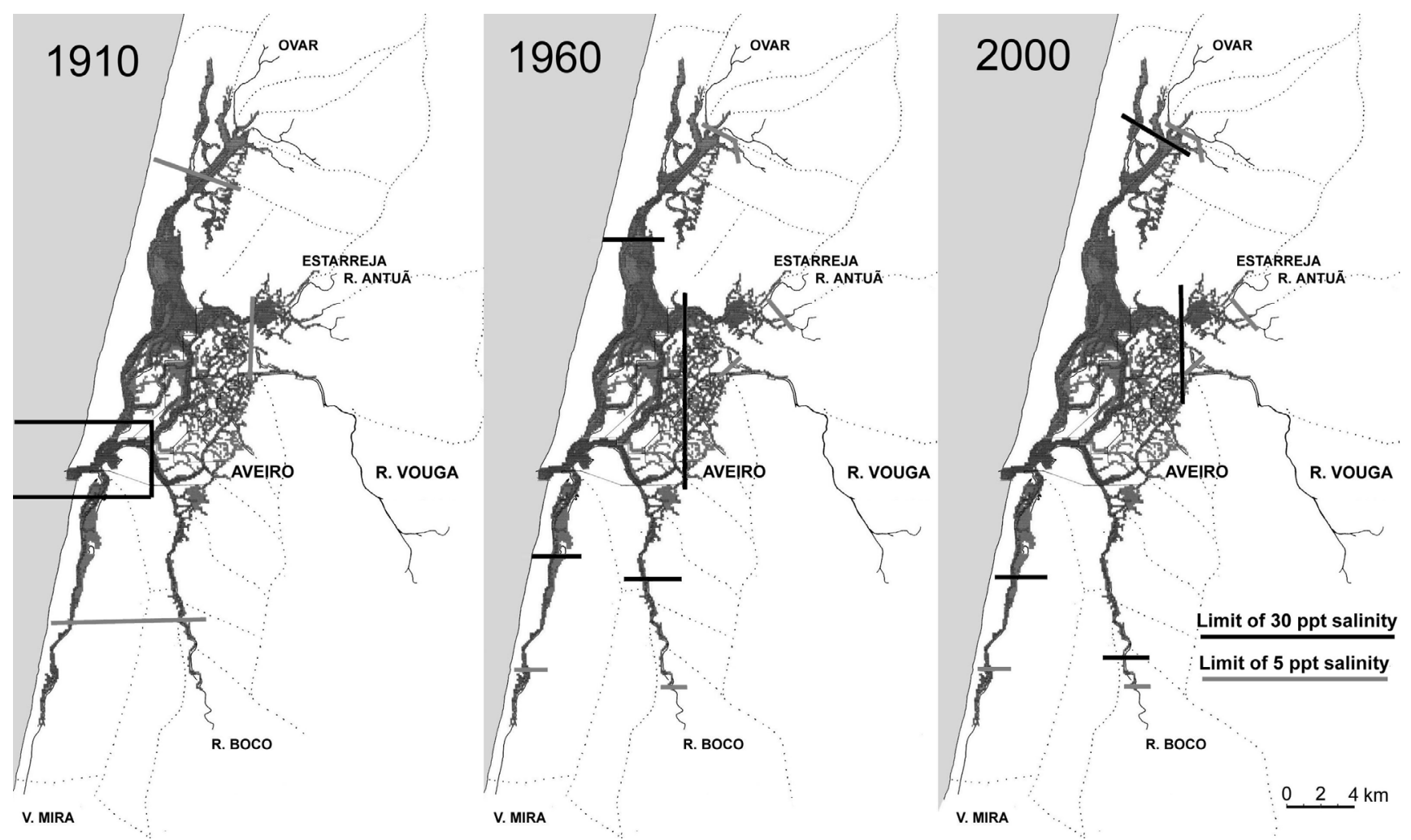

Fig 5. Salinity zones: change from 1910 to 2000.

zone. Today, seagrasses have disappeared from all of the sub-tidal zones of the Ria de Aveiro system.

\section{Human interference: collection of seagrasses in the Ria de Aveiro}

For centuries, the collection of seagrasses for agricultural fertiliser to apply to the land, has been a traditional industry in the Ria de Aveiro. Although raking from sailing boats caused some disturbance and resuspension of the bottom sediments, a productive mat was maintained. This activity employed up to over 1400 boats at the end of the $19^{\text {th }}$ century (Fig. 8). Thereafter, the number of boats involved in seagrass collection declined steadily, especially after 1960 (Fig. 8); Lopes (1968) attributes this to social and economic factors, rather than the absences of seagrasses. At the peak of the industry, from the $1880 \mathrm{~s}$ until the $1930 \mathrm{~s}$, more than $2 \times 10^{5} \mathrm{t}$ 

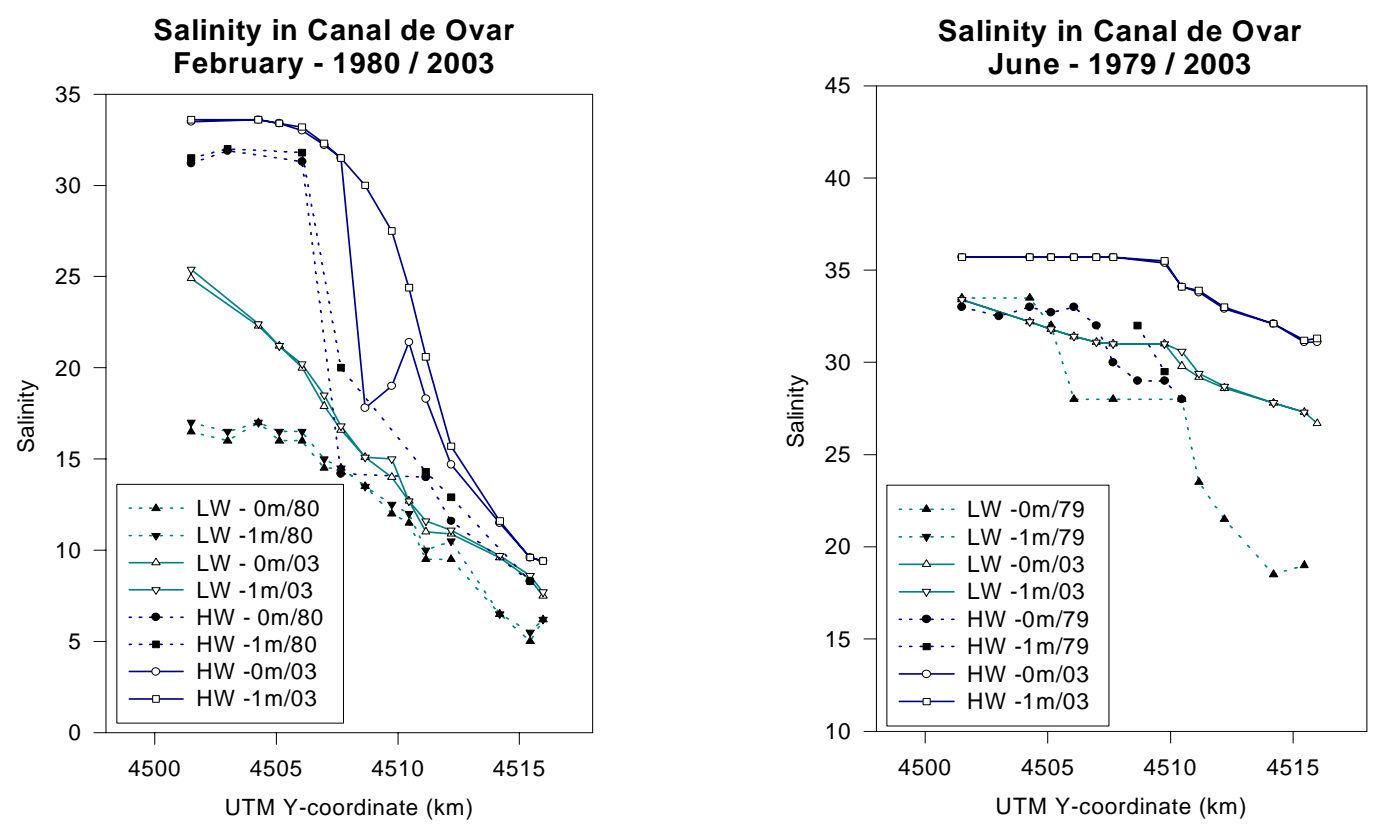

Fig. 6. Variation in salinity (psu) along the Canal de Ovar. Left panel compares salinity profile in February 1979 and 2003. Right panel compares salinity profile in June 1979 and 2003.
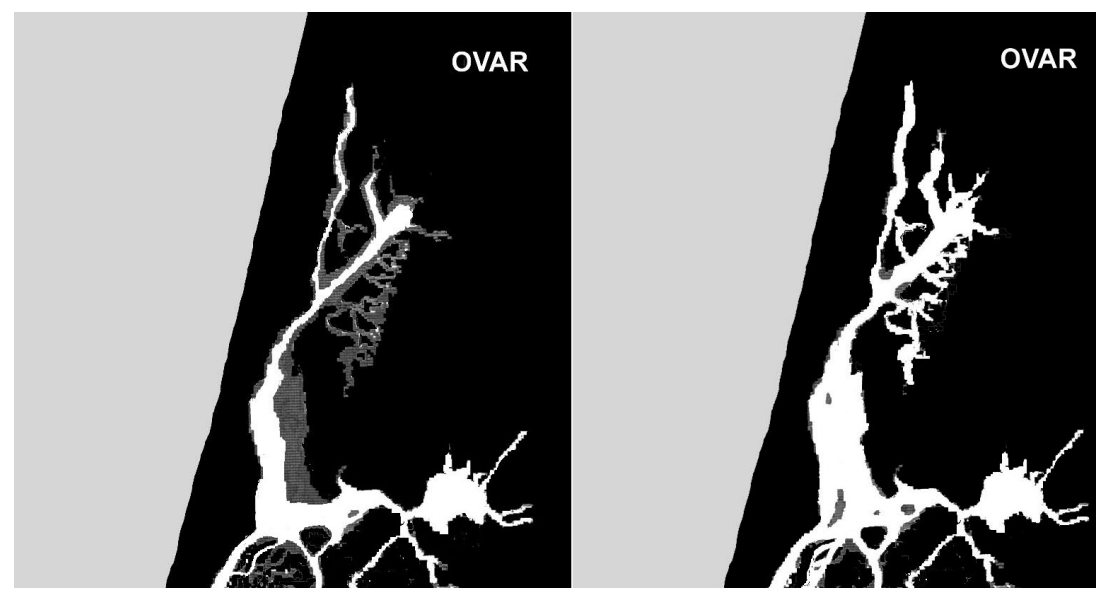

Fig. 7. Comparison of areas covered by seagrasses in the Canal de Ovar in 1984 and 2003, marked in grey. Left panel: the area vegetated in 1984 includes most sub-tidal shallow zones. Right panel: the area vegetated in 2003 is limited to inter-tidal zones.

Table 2. Mean values and standard deviation of dry weight and $\%$ loss at $550^{\circ} \mathrm{C}$, of vegetation samples collected in intertidal locations in the Canal de Ovar between September 2002 and June 2003.

\begin{tabular}{|c|c|c|c|c|c|c|c|c|}
\hline & \multicolumn{2}{|l|}{ Zostera } & \multicolumn{2}{|l|}{ Gracilaria } & \multicolumn{2}{|c|}{ Enteromorpha } & \multicolumn{2}{|l|}{ Ulva } \\
\hline & $\begin{array}{l}\text { Dry weight } \\
\left(\mathrm{g} \mathrm{m}^{-2}\right)\end{array}$ & $\%$ volatile & $\begin{array}{l}\text { Dry weight } \\
\left(\mathrm{g} \mathrm{m}^{-2}\right)\end{array}$ & $\%$ volatile & $\begin{array}{l}\text { Dry weight } \\
\left(g \mathrm{~m}^{-2}\right)\end{array}$ & $\%$ volatile & $\begin{array}{l}\text { Dry weight } \\
\left(\mathrm{g} \mathrm{m}^{-2}\right)\end{array}$ & $\%$ volatile \\
\hline \multicolumn{9}{|c|}{ SAMPLES WITH ZOSTERA } \\
\hline Mean & 154 & 64 & 41 & 67 & & & 17 & 51 \\
\hline Standard deviation & 142 & 17 & 60 & 3 & & & 56 & 10 \\
\hline \multicolumn{9}{|c|}{ SAMPLES WITH ALGAE ONLY } \\
\hline Mean & & & 5 & 50 & 25 & 37 & 3 & 41 \\
\hline Standard deviation & & & 8 & 25 & 52 & 21 & 7 & 26 \\
\hline
\end{tabular}



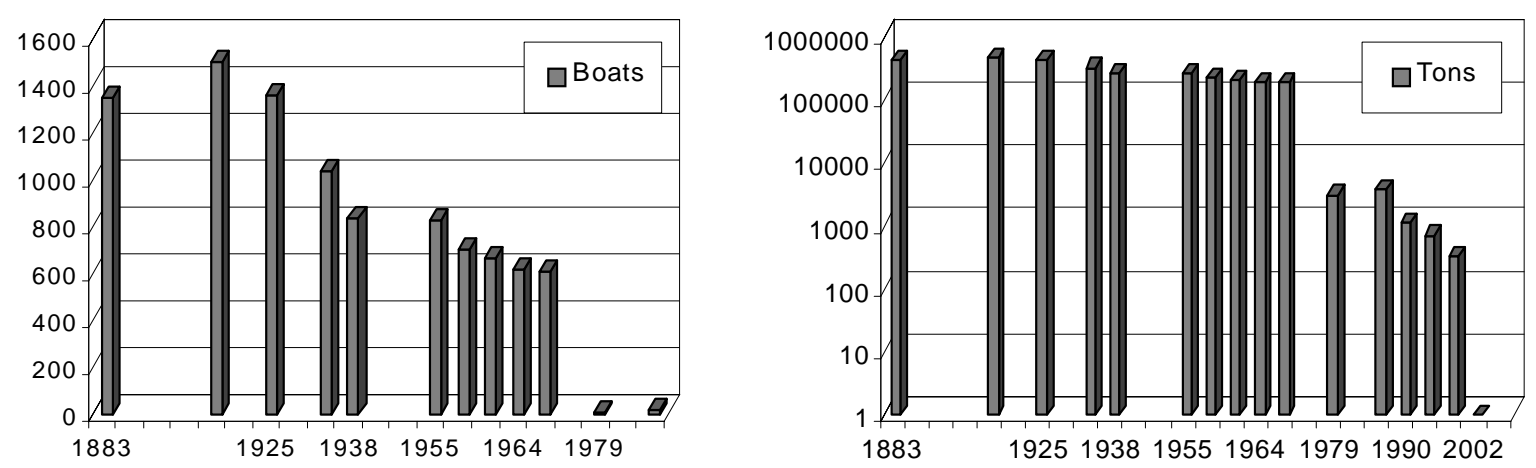

Fig 8. Change through time in the number of boats used for collecting seagrasses and of the amounts collected.

of sea grasses were collected per year (Sousa, 1936a; Santos and Duarte, 1991). The industry declined after the 1960s and, by the mid-1980s to 1990 s, collection had become reduced to $4 \times 10^{3}$ t per year. Seagrasses were still abundant at this time, as evidenced by the observations from the Canal de Ovar in 1984 described above. A financial incentive for seagrass collection, provided in the late $1980 \mathrm{~s}$, resulted in a slight increase in the amounts collected. However, commercial seagrass collection ceased completely in the Ria de Aveiro in 1998 after the sharp decrease in the sub-tidal populations.

\section{Changes in sedimentary regime}

Data relating to grain size analyses of bottom sediments from the Canal de Ovar collected in 1979 are compared with those of 2002 in Fig. 9. The samples were collected at the same set of locations, which were classified into four types on the basis of elevation relative to low water mark in conjunction with observations of seagrass occurrence. These four classes take into consideration the importance of the exposure of the sediment to current velocity stress. The four classes are:

- Class I - sediments of sub-tidal zones colonised by seagrasses (present in 1979 only: I-79)

- Class II - sediments of sub-tidal zones, unvegetated (present in both 1979 and 2002: II-79 and II-02)

- Class III - sediments of inter-tidal zones colonised by Zostera (present in both 1979 and 2002: III-79 and III02)

- Class IV - sediments of inter-tidal zones, unvegetated (present in both 1979 and 2002: IV-79 and IV-02)

The 1979 data show that the bottom sediments of subtidal zones with seagrasses (I-79, Fig. 9) were typified by median diameters mainly below $30 \mu \mathrm{m}$. Unvegetated sub-

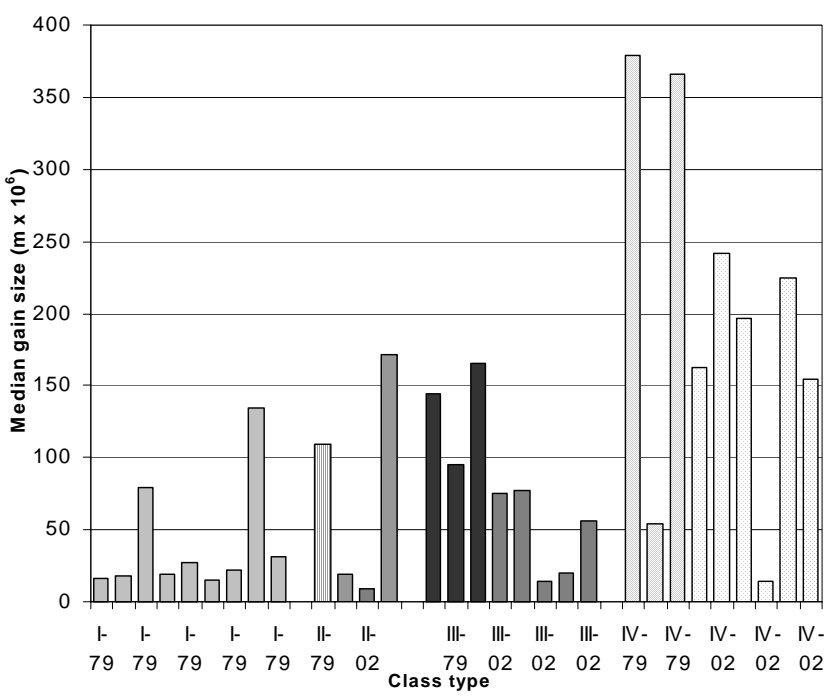

Fig 9. Median grain size of sediment samples from the Canal de Ovar, classified on the basis of the elevation relative to low water mark and seagrass occurrence (see text for details).

tidal zones (II-79) were, however, characterised by coarser sediments with median grain sizes ranging from $50->350 \mu \mathrm{m}$. By 2002, seagrasses were entirely absent from such sub-tidal areas and the sediments of these unvegetated zones (II-02) were quite variable with median grain sizes ranging from 10 to $160 \mu \mathrm{m}$. Inter-tidal zones colonised by Zostera were, in 1979, typified by deposits (III-79) with median grain sizes in the range 100-150 $\mu \mathrm{m}$. By 2002 , however, the sediments of these areas (III-02) had become finer, with median grain sizes typically between 20 and $60 \mu \mathrm{m}$. There is also an apparent reduction in grain size of the sediments of the unvegetated inter-tidal zones, with median values falling from $>350 \mu \mathrm{m}$ in 1979 (IV-79) to 150-240 $\mu \mathrm{m}$ in 2002 (IV-02). However, the unvegetated inter-tidal areas in 2002 (IV-02) were characterised by much coarser sediments than the inter-tidal zones of 1979 (III- 
79) and of 2002 (III-02) which were covered by Zostera. Similarly, the sediments of the unvegetated sub-tidal zones of 2002 (II-02) showed, in some areas, a coarsening of median grain size as compared with the seagrass colonised sub-tidal zones in 1979 (I-79).

The grain size classes that are now (2002) more abundant are silt (mean content of 61\%) in areas with Zostera, and fine sand in areas without Zostera (mean sand content of $69 \%$ ). However, the clay component, normally less than $12 \%$, can accumulate to $30 \%$ in very protected inter-tidal areas. In 1979, the sub-tidal areas with seagrasses had a mean clay content of $16 \%$ and a mean silt content of $47 \%$. Taking into consideration that the area now covered by seagrass is small, the general trend of sediment textural change, between 1979 and 2002, corresponds to an increase in the median size of the bed surface sediments.

\section{Discussion: factors causing seagrass decline}

The factors potentially responsible for the decline in seagrasses within the Ria de Aveiro are change in tidal related physical forcing, salinity, turbidity and sedimentation, together with dredging operations and seagrass harvesting. However, the decline in the seagrass industry, prior to the period of subsidy in the early 1990s, was due to social and economic drivers rather than an absence of seagrasses, so over-harvesting may be discounted as the cause of their disappearing from sub-tidal areas.

This morphodynamic trend associated with the evolution of the Ria de Aveiro system as described above suggests a progressively increasing capacity for sediment transport and dispersal, related to the increase in tidal prism and associated tidal currents (Silva and Duck, 2001). The texture of the sediment on the bed of the ria reflects the hydrodynamic conditions prevailing when it was deposited. The change of hydrodynamic conditions, associated with the deepening of the connection to the ocean, is likely to have caused increased sediment mobilisation and redistribution resulting in changes in the textural characteristics of the bottom deposits. This is confirmed by the observations of sediment grain size distribution in the Canal de Ovar, presented in terms of median grain size in Fig. 9. These indicate that, in general, the deposits of sub-tidal zones formerly colonised by seagrasses in 1979 were, by 2003, replaced by coarser, sandy sediments. The deposits of the unvegetated inter-tidal zones in 2002 (II-02, Fig. 9) were quite variable; in some parts what is interpreted as relict fine grained sediment was present, in others the sandy sediments are thought to be due to the deposition of materials eroded from deeper areas. Whilst the finer fraction is transported from the eroding deeper channel areas and deposited in more protected areas, the remaining coarser, sandy sediment becomes mobilised into dune bedforms that partially cover older, finer grained sediments.

Until the 1950s, the hydrodynamic conditions in the Ria de Aveiro were those of a restricted lagoon (Kefevre, 1994). Tidal oscillation was less than half of that observed in the ocean and tidal flows caused slow currents. Under these conditions, influent river discharge, sediment and nutrient loads had a large effect on the salinity, sediment deposition and the growth of submerged vegetation in the lagoon. These conditions favoured the accumulation of fine sediment in sub-tidal areas covered by seagrasses and brackish water plants, while supporting salt marsh vegetation on the higher inter-tidal flats. Most of the sub-tidal flats were then covered by brackish water species (Ruppia cirrhosa and Potamogeton pectinatus) and, near the inlet, by seagrasses of the Zostera genus. This situation would normally promote rapid siltation of the bed but the accumulation of fine sediment was in part controlled by the collection of the macrophytes for fertilizer, causing mobilisation of the sediment. This activity contributed to maintaining relatively flat, stable sub-tidal areas.

From 1910 to 1960, the salinity in the central area of the lagoon of the Ria de Aveiro increased from values typical of the transition zone to that of fully marine conditions. During the 1930s, Sousa (1936b) reported that Z. noltii was the most abundant species in this area. Nevertheless, by the 1970s, Zostera (fully marine genus) had disappeared completely from the sub-tidal parts of the area close to the inlet channel (I.D.E.S.O., 1973). From 1960 to 1990, the summer salinity in the Canal de Ovar also increased to oceanic values and yet, by 2000 , all sub-tidal seagrasses, including Zostera noltii, had disappeared completely. The increase in salinity could not, therefore, be the sole cause of seagrass decline.

Experimental studies have shown that increases in nitrate can reduce the size of Zostera marina shoots significantly (Touchette et al., 2003). However, increased nitrate concentrations are not thought to be a significant factor in the recent disappearance of seagrasses from the Ria de Aveiro; nitrate concentrations in the system are likely to have been reduced by the increase in tidal prism (Silva and Duck, 2001) and, thus, by the shorter residence time of river water inside the lagoon.

After the 1950s, the ongoing dredging operations in the inlet and navigation channels caused a gradual increase in the amplitude of lagoon tides. The deepening of the channels had a larger effect on the high water levels in the inner parts of the lagoon, thus the inter-tidal area increased because of the higher high water level. The lowering of low water levels 
was a more gradual process, occurring as the sediment was redistributed in response to the changed hydrodynamic conditions. The faster tidal flows, induced by the increased tidal prism, caused the mobilisation of sandy sediment from the deeper channels to the tidal flats nearby. The stress imposed on the vegetation caused it to disappear from the sub-tidal areas, which became more subject to erosion.

In a discussion of factors controlling the distribution and abundance of seagrasses, Hemminga and Duarte (2000) report a reduction in species richness with increasing siltation. They further note that the light requirements for seagrass growth are greater than those generally observed for macroalgae. High mobility of fine sediments caused by currents and waves renders them unsuitable to support plant growth. Seagrass populations are, thus, highly sensitive to sediment dynamics. When seagrasses disappear from an area, an unstable sediment typically remains; this can be susceptible to erosion and resuspended, thereby influencing water quality (e.g. De Falco et al., 2000).

\section{Conclusions}

In this paper, the extent and rapidity of seagrass decline in the Ria de Aveiro over time has been demonstrated and contributory factors highlighted, whilst the specific activity of seagrass harvesting has been excluded as a possible cause. Of the several factors identified in this investigation that may cause stress to the $Z$. noltii seagrass populations, the most important in the Ria de Aveiro are thought to be changes in sediment stability, mobility and water turbidity. While the brackish water species $R$. cirrhosa and $P$. pectinatus, formerly abundant in the inner channel areas, may have disappeared in response to an increase in salinity (e.g. Canal de Ovar), these species were not replaced by Z. noltii, which is a fully marine species. Whilst further research is ongoing, this investigation suggests that the underlying cause of seagrass decline has been the increase in physical forcing in the system because of. increased tidal wave penetration; this, in turn, induced transport and redistribution of sandy sediment. The resuspension associated with the faster tidal flows has increased turbidity in the water column, thereby reducing light penetration. However, the initial cause for this ecosystem change was dredging, which, over 50 years, has been employed increasingly to widen and deepen the channels of the system, thus exacerbating the changes in tidal forcing and sediment dynamics

\section{Aclnowledgements}

The authors gratefully acknowledge financial support for this study from Fundação para a Ciência e a Tecnologia, Programa Operacional do Quadro Comunitário de Apoio III provided to the project POCTI/42893/MGS/2001.

\section{References}

Carvalho, L.G., 1947. Memória Descritiva. Arquivo do Distrito de Aveiro, XIII: 20-113.

De Falco, G., Ferrari, S., Cancemi, G. and Baroli, M., 2000. Relationship between sediment distribution and Posidonia oceanica seagrass. Geo-Marine Letters, 20, 50-57.

Hemminga, M.A. and Duarte, C.M., 2000. Seagrass Ecology. Cambridge University Press, Cambridge, UK. 298 pp

I.D.E.S.O., 1973. Curso de iniciação à investigação científica: Ria de Aveiro-II, 53 pp.

Kefevre, B., 1994. Coastal lagoons. In: Coastal Lagoon Processes, B. Kjerfve (Ed.), Elsevier, Amsterdam, The Netherlands. 1-8.

Leitão, 1906., A Bacia Hydrographica de Aveiro e a Salubridade Publica. Imprensa Portugueza, Porto, Portugal.

Lopes, A.S., 1968. O problema do moliço na Ria de Aveiro. Aveiro e o seu Distrito, 5, 23-33. Portugal.

Loureiro, A., 1904. Os Portos Maritimos de Portugal e Ilhas Adjacentes - Porto de Aveiro. Imprensa Nacional, Lisboa, Portugal.

Nobre, A., Afreixo, J. and Macedo, J., 1915. A Ria de Aveiro. Imprensa Nacional, Lisboa, Portugal.

Rodrigues, D., Teles, M., del Negro, M., Ventura, A. and Rita, A., 1989. Modelação Matemática da Ria de Aveiro. Relatório de Progressão, Hidroprojecto, Lisboa, Portugal.

Santos, R. and Duarte, P., 1991. Marine plant harvest in Portugal. J. Appl. Phycol. 3, 11-18.

Silva, J.F., 1985. O moliço da Ria de Aveiro. Jornadas da Ria de Aveiro, II, 223-251, Câmara Municipal de Aveiro, Portugal.

Silva, J.F. and Duck, R.W., 2001. Historical changes of bottom topography and tidal amplitude in the Ria de Aveiro, Portugal trends for future evolution. Climate Res., 18, 17-24.

Sousa, T.T., 1936a. Os moliços: quantidade de moliços; seu valor. Licenças de apanha e transporte. Arquivo do Distrito de Aveiro, II, 57-64.

Sousa, T.T., 1936b. Os moliços: Flora dos moliços; localização de produção das várias espécies. Arquivo do Distrito de Aveiro, II, 177-190.

Teixeira, S.L., 1994. Dinâmica Morfossedimentar da Ria de Aveiro (Portugal). Tese de Doutoramento, Universidade de Lisboa, Portugal.

Touchette, B.W., Burkholder, J.M. and Glasgow Jr., H.B., 2003. Variations in eelgrass (Zostera marina L.) morphology and internal nutrient composition as influenced by increased temperature and water column nitrate. Estuaries, 26, 142-155. 